\title{
Is there a sodium effect in fibrillar amyloid- $\beta$ oligomers?
}

\author{
Anselm HC Horn", Danyil Huraskin, Heinrich Sticht \\ From 9th German Conference on Chemoinformatics \\ Fulda, Germany. 10-12 November 2013
}

Hall mark in Alzheimer's Disease (AD) is the aggregation of amyloid- $\beta$ (A $\beta$ ) peptide into oligomers and fibrils. Nowadays, the soluble oligomers are believed to be the most neurotoxic species, probably the causative agents in AD. Amyloid-beta fibrils on the other hand may serve as reservoirs for small toxic oligomers. While it is well known from experiment, that the aggregation process is modulated by salt concentration in solution, the molecular details of the underlying interactions are not.

Salts occur ubiquitously in physiological environments and are known to have profound effects on the solubility of proteins (Hofmeister series). Monovalent alkali metal ions exhibit a more subtle effect on $A \beta$ aggregation in experiment than doubly charged species $[1,2]$.

In this contribution we investigate the presence of the so-called 'sodium-effect' in fibrillar $A \beta$ oligomers. This effect was originally described for dendrimer micelles formation modulating the self-organization of amphiphilic carboxylates: $\mathrm{Na}+$ forms bridging complexes with carboxylate groups, in contrast to $\mathrm{K}+[3]$.

Molecular dynamics simulations for a systematic series of single and double layer fibrillar $A \beta$ oligomers in aqueous $150 \mathrm{mM}$ salt solution provide insights about the stabilizing interactions between the cations and charged $A \beta$ key residues (e.g. Glu22). Comparison with a previous computational study at low ion concentration [4] show similarities and differences on a structural level. Interestingly, ions access the $A \beta$ water channel region via entry paths suggested previously [4].

References

1. Mantyh PW, Ghilardi JR, Rogers S, DeMaster E, Allen CJ, Stimson ER, Maggio JE: Aluminum, iron, and zinc ions promote aggregation of physiological concentrations of beta-amyloid peptide. J Neurochem 1993, 61:1171-1174.

2. Klement K, Wieligmann K, Meinhardt J, Hortschansky P, Richter W, Fändrich MJ: Effect of different salt ions on the propensity of aggregation and on the structure of Alzheimer's abeta(1-40) amyloid fibrils. Mol Biol 2007, 373:1321-1333.

3. Rosenlehner K, Schade B, Böttcher C, Jäger CM, Clark T, Heinemann FW, Hirsch A: Sodium effect on self-organization of amphiphilic carboxylates: formation of structured micelles and superlattices. Chem Eur J 2010, 16:9544-9554

4. Kahler A, Sticht H, Horn AHC: Conformational Stability of Fibrillar Amyloid-Beta Oligomers via Protofilament Pair Formation - A Systematic Computational Study. PLOS ONE 2013, 8:e70521.

doi:10.1186/1758-2946-6-S1-P56

Cite this article as: Horn et al:: Is there a sodium effect in fibrillar amyloid- $\beta$ oligomers? Journal of Cheminformatics 2014 6(Suppl 1):P56.
Publish with ChemistryCentral and every scientist can read your work free of charge

"Open access provides opportunities to our colleagues in other parts of the globe, by allowing anyone to view the content free of charge."

W. Jeffery Hurst, The Hershey Company.

- available free of charge to the entire scientific community

- peer reviewed and published immediately upon acceptance

- cited in PubMed and archived on PubMed Central

- yours - you keep the copyright

Submit your manuscript here:

http://www.chemistrycentral.com/manuscript/ 